\title{
Keberhasilan Terapi Konservatif pada Persalinan Preterm Disertai dan Tanpa Disertai Ketuban Pecah Dini di RSD dr. Soebandi, Jember
}

\section{(The Success of Conservative Therapy in Preterm Delivery with and without Premature Rupture of Membranes at $R S D$ dr. Soebandi, Jember)}

\author{
Nurul Furqooniyah ${ }^{1}$, Yonas Hadisubroto ${ }^{2}$, Bagus Hermansyah ${ }^{3}$ \\ ${ }^{1}$ Faculty of Medicine, University of Jember \\ ${ }^{2}$ Departement of Obstetry and Gynaecology, Faculty of Medicine, University of Jember \\ ${ }^{3}$ Departement of Parasitology, Faculty of Medicine, University of Jember \\ J. Kalimantan No. 37 Jember, 68121 \\ e-mail: nurulfurqon7@gmail.com
}

\begin{abstract}
Preterm delivery is the greatest cause of neonatal morbidity and mortality. Preterm delivery can be accompanied by premature rupture of membranes. Preterm delivery with and without premature rupture of membranes are managed by conservative therapy to delay birth. Rupture of membranes causes inadequate protection of the fetus. This study aimed to determine the success of conservative therapy in preterm delivery with and without premature rupture of membranes at Regional Hospital (RSD) $d r$. Soebandi Jember. The study used secondary data from medical records of pregnant women with spontaneous single preterm delivery that has been given conservative treatment from January 2015January 2017 period. As many as 149 samples were included for the study, which is collected using total sampling technique. This research used cross sectional research design. Chi-Square statistical test results showed a significance of $(p=0.001<0.05)$. It can be concluded that there was a significant difference of the success of conservative therapy between the preterm delivery with and without premature rupture of membranes.
\end{abstract}

Keywords: conservative therapy, preterm delivery, premature rupture of membranes

\begin{abstract}
Abstrak
Persalinan preterm merupakan penyebab terbesar morbiditas dan mortalitas neonatal. Persalinan preterm dapat disertai dengan ketuban pecah dini. Persalinan preterm disertai dan tanpa disertai ketuban pecah dini keduanya diberikan terapi konservatif untuk menunda kelahiran. Pecahnya selaput ketuban menyebabkan perlindungan bagi janin kurang adekuat. Penelitian ini bertujuan untuk mengetahui adanya perbedaan keberhasilan terapi konservatif antara persalinan preterm disertai dan tanpa disertai ketuban pecah dini di Rumah Sakit Daerah (RSD) dr. Soebandi Jember menggunakan data sekunder berupa catatan rekam medis ibu hamil dengan persalinan preterm tunggal spontan yang telah diterapi konservatif periode Januari 2015-Januari 2017 sebanyak 149 sampel dikumpulkan dengan metode total sampling. Penelitian ini menggunakan desain penelitian cross sectional. Hasil uji statistik Chi-Square, menunjukkan significancy $(p=0,001<0,05)$ sehingga dapat disimpulkan bahwa ada perbedaan yang signifikan dari keberhasilan terapi konservatif antara persalinan preterm disertai dan tanpa disertai ketuban pecah dini.
\end{abstract}


Kata kunci: keberhasilan terapi konservatif, persalinan preterm, ketuban pecah dini

\section{Pendahuluan}

Kematian bayi baru lahir menyumbang $45 \%$ kematian pada anak-anak di bawah usia lima tahun. Mayoritas dari semua kematian tersebut $(75 \%)$ terjadi pada minggu pertama kehidupan, dan antara $25 \%$ sampai $45 \%$ terjadi dalam 24 jam pertama. Penyebab utama kematian bayi baru lahir adalah prematuritas dalam persalinan preterm, berat bayi lahir rendah, infeksi, asfiksia (kekurangan oksigen saat lahir) dan trauma kelahiran. Penyebab tersebut menyebabkan hampir $80 \%$ kematian pada kelompok usia ini (dibawah lima tahun) [1].

Persalinan preterm adalah persalinan sebelum usia kehamilan 37 minggu dan merupakan penyebab terbesar morbiditas dan mortalitas neonatal [2]. Di dunia diperkirakan 15 juta bayi lahir terlalu dini setiap tahun. Hampir satu juta anak meninggal setiap tahun karena komplikasi persalinan preterm. Bayi yang selamat sebagian besar menghadapi kecacatan seumur hidup, termasuk ketidakmampuan belajar dan masalah visual serta pendengaran [3]. Angka kejadian persalinan preterm di Indonesia cukup besar yaitu berkisar 675.700 kasus per tahun. Angka ini menyebabkan Indonesia menempati peringkat kelima negara dengan persalinan preterm terbesar [4]. Berdasarkan hasil studi pendahuluan di RSD dr. Soebandi terdapat sekitar 90 kasus persalinan preterm per bulan.

Persalinan preterm dapat disertai dengan kelainan atau penyakit lain yang menyertai kehamilan, salah satunya yakni ketuban pecah dini. Ketuban pecah dini adalah keadaan pecahnya selaput ketuban sebelum proses persalinan. Bila ketuban pecah dini terjadi sebelum usia kehamilan 37 minggu disebut ketuban pecah dini pada kehamilan prematur [5]. Ketuban pecah dini menjadi determinan dari persalinan preterm $(p=0,005)$ setelah komplikasi kehamilan dan paritas berdasarkan penelitian yang dilakukan di RSD dr. Abdul Moeloek Bandar Lampung menggunakan data rekam medis tahun 2012-2016 [6]. Persalinan preterm disertai ketuban pecah dini dan tanpa disertai ketuban pecah dini keduanya diberikan terapi konservatif untuk menunda kelahiran bayi berupa tokolitik, kortikosteroid, dan antibiotika [7]. Ketuban pecah dini yang dibahas pada penelitian ini merupakan ketuban pecah dini prematur yang diberi terapi konservatif yakni yang berada pada usia kehamilan 24 - 33 minggu.

Pecahnya selaput ketuban menyebabkan perlindungan bagi janin kurang adekuat sehingga peran utama selaput ketuban untuk mempertahankan kehamilan kurang maksimal [8]. Adanya perbedaan kondisi dari selaput ketuban antara persalinan preterm yang disertai dan tanpa disertai ketuban pecah dini memungkinkan adanya perbedaan keberhasilan dari terapi konservatif yang dilakukan pada kedua kasus tersebut. Penelitian tentang hasil keluaran bayi pada persalinan preterm disertai ketuban pecah dini dan tanpa disertai ketuban pecah dini yang dilakukan terapi konservatif sudah banyak dilakukan [9][10][11]. Sedangkan, penelitian tentang keberhasilan terapi konservatif pada keduanya masih sedikit yang meneliti. Terapi konservatif dikatakan berhasil apabila dapat mempertahankan bayi dalam rahim sehingga ibu hamil diperbolehkan untuk pulang. Tujuan penelitian ini untuk menganalisis perbedaan keberhasilan terapi konservatif antara persalinan preterm disertai dan tanpa disertai ketuban pecah dini di Rumah Sakit Daerah (RSD) dr. Soebandi Kabupaten Jember.

\section{Metode Penelitian}

Penelitian ini sudah mendapatkan perizinan etik No. 1.161/H25.1.11/KE/2017 dari Komisi Etik Penelitian Fakultas Kedokteran Universitas Jember. Penelitian ini menggunakan desain studi cross sectional. Penelitian dilakukan di Rumah Sakit Daerah dr. Soebandi Kabupaten Jember. Sampel yang digunakan yaitu semua kasus persalinan preterm tunggal spontan sesuai kriteria inklusi dan eksklusi yang didapat dari catatan rekam medis RSD dr. Soebandi periode Januari 2015 - Januari 2017 dengan standar minimal 30 kasus[12].

Kriteria inklusi dari penelitian ini adalah Ibu dengan kehamilan tunggal dengan persalinan preterm spontan disertai atau tanpa disertai ketuban pecah dini pada usia kehamilan 24-33 minggu. Terdapat beberapa kriteria eksklusi, yakni: (1) Kelainan kongenital bayi dan Ibu hamil; (2) Preeklamsi/Eklamsi; (3) Anemia; (4) Gemelli; (4) Polihidramnion; (5) Perdarahan antepartum; (6) Pasien pulang paksa; (7) Riwayat persalinan preterm.

Sampel yang telah diperoleh dibagi menjaadi dua kelompok yaitu kelompok 
Furqooniyah, et al., Keberhasilan Terapi Konservatif pada persalinan Preterm Disertai dan Tanpa .....

persalinan preterm yang disertai ketuban pecah dini dan kelompok persalinan preterm tanpa ketuban pecah dini. Kemudian kedua kelompok tersebut akan dikelompokkan menjadi dua kelompok berdasarkan hasil akhir dari terapi konservatif yaitu berhasil dan gagal. Analisis data dilakukan dengan program Statistical Package for the Social Sciences (SPSS) 23.0. Analisis dilakukan dalam dua tahap, yaitu analisis univariat yang disajikan dalam bentuk distribusi frekuensi dan analisis bivariat uji statistik komparatif dengan uji ChiSquare.

\section{Hasil}

Pada penelitian ini diperoleh 149 sampel yang memenuhi kriteria sampel dari 458 ibu hamil di dalam populasi. Distribusi sampel berdasarkan keberhasilan terapi konservatif disajikan pada Tabel 1.

Tabel 1. Distribusi keberhasilan terapi konservatif

\begin{tabular}{|c|c|c|}
\hline $\begin{array}{c}\text { Keberhasilan } \\
\text { Terapi } \\
\text { Konservatif }\end{array}$ & $\begin{array}{c}\text { Jumlah } \\
\text { Sampel } \\
\text { (orang) }\end{array}$ & $\begin{array}{c}\text { Persentase } \\
(\%)\end{array}$ \\
\hline Berhasil & 56 & 37,6 \\
\hline Gagal & 93 & 62,4 \\
\hline Jumlah & 149 & 100 \\
\hline
\end{tabular}

Distribusi ketuban pecah dini ibu yang telah mengalami persalinan preterm tunggal spontan dalam penelitian ini disajikan pada Tabel 2.

Tabel 2. Distribusi ketuban pecah dini

\begin{tabular}{|c|c|c|}
\hline $\begin{array}{c}\text { Jenis } \\
\text { Persalinan } \\
\text { Peterm }\end{array}$ & $\begin{array}{c}\text { Jumlah } \\
\text { Sampel } \\
\text { (orang) }\end{array}$ & $\begin{array}{c}\text { Persentase } \\
(\%)\end{array}$ \\
\hline Disertai KPD & 90 & 60,4 \\
\hline $\begin{array}{c}\text { Tanpa Disertai } \\
\text { KPD }\end{array}$ & 59 & 39,6 \\
\hline Jumlah & 149 & 100 \\
\hline
\end{tabular}

Distribusi usia kehamilan ibu saat mengalami persalinan pada penelitian ini disajikan pada Tabel 3.

Tabel 3. Distribusi usia kehamilan

\begin{tabular}{|c|c|c|}
\hline $\begin{array}{c}\text { Usia } \\
\text { Kehamilan } \\
\text { (minggu) }\end{array}$ & $\begin{array}{c}\text { Jumlah } \\
\text { Sampel } \\
\text { (Orang) }\end{array}$ & $\begin{array}{c}\text { Persentase } \\
(\%)\end{array}$ \\
\hline $24-25$ & 9 & 6 \\
\hline $25-26$ & 3 & 2 \\
\hline $26-27$ & 3 & 2 \\
\hline $27-28$ & 13 & 8,7 \\
\hline $28-29$ & 16 & 10,7 \\
\hline $29-30$ & 13 & 8,7 \\
\hline $30-31$ & 11 & 7,4 \\
\hline $31-32$ & 33 & 22,2 \\
\hline $32-33$ & 48 & 32,2 \\
\hline Jumlah & 149 & 100 \\
\hline
\end{tabular}

Distribusi keberhasilan terapi konservatif antara persalinan preterm disertai dan tanpa disertai ketuban pecah dini disajikan pada Tabel 4.

Tabel 4. Distribusi keberhasilan terapi konservatif antara persalinan preterm disertai dan tanpa disertai ketuban pecah dini

\begin{tabular}{|l|c|c|c|c|}
\hline \multirow{2}{*}{$\begin{array}{l}\text { Persalin } \\
\text { an }\end{array}$ Preterm } & \multicolumn{3}{|c|}{ Keberhasilan Terapi Konservatif } \\
\cline { 2 - 5 } & $\begin{array}{c}\text { Jumlah } \\
\text { (orang) }\end{array}$ & $\begin{array}{c}\text { Persen } \\
\text { tase } \\
(\%)\end{array}$ & $\begin{array}{l}\text { Jumlah } \\
\text { (orang) }\end{array}$ & $\begin{array}{l}\text { Persen } \\
\text { tase } \\
(\%)\end{array}$ \\
\hline $\begin{array}{c}\text { Disertai } \\
\text { KPD }\end{array}$ & 24 & 16,1 & 66 & 44,3 \\
\hline $\begin{array}{c}\text { Tanpa } \\
\text { Disertai } \\
\text { KPD }\end{array}$ & 32 & 21,5 & 27 & 18,1 \\
\hline Jumlah & 56 & 37,6 & 93 & 62,4 \\
\hline
\end{tabular}

Untuk mengetahui perbedaan keberhasilan terapi konservatif antara persalinan 
preterm disertai dan tanpa disertai ketuban pecah dini di RSD dr. Soebandi Kabupaten Jember, sampel akan dianalisis bivariat dengan uji nonparametrik Chi-Square. Hasil uji ChiSquare disajikan pada Tabel 5.

Tabel 5. Hasil uji Chi-Square

\begin{tabular}{|l|c|}
\hline & $\begin{array}{c}\text { Asymp. Sig. (2- } \\
\text { sided) }\end{array}$ \\
\hline Pearson Chi-Square &, 001 \\
\hline Continuity Correctionb &, 001 \\
\hline Likelihood Ratio &, 001 \\
\hline N of Valid Cases & 149 \\
\hline
\end{tabular}

*signifikan $(p<0,05)$

\section{Pembahasan}

Hasil analisis dengan uji Chi-Square didapatkan hasil $p=0,001$ yang berarti secara statistik ada perbedaan yang signifikan dari keberhasilan terapi konservatif antara persalinan preterm disertai dan tanpa disertai ketuban pecah dini. Sampel dengan persalinan preterm disertai ketuban pecah dini yang diberikan terapi konservatif berjumlah 90 sampel. Dari jumlah tersebut, sampel yang berhasil diterapi konservatif lebih sedikit dari pada sampel yang gagal dalam terapi konservatif yaitu 24 dibanding 66 (kurang dari setengah jumlah keseluruhan). Kegagalan terapi konservatif pada persalinan preterm disertai ketuban pecah dini mencerminkan kondisi yang sesuai teori bahwa ketuban pecah dini dapat memicu persalinan preterm [8], sehingga terapi konservatif yang diberikan memiliki kemungkinan besar untuk gagal dalam mempertahankan bayi tetap di dalam rahim ibu hamil.

Struktur avaskular dari selaput ketuban memiliki peran penting dalam kehamilan. Bagian dalam dari selaput amnion merupakan mikrovili yang berfungsi mentransfer cairan dan metabolik, lapisan ini juga dapat menghasilkan zat penghambat metalloproteinase-1 [13]. Matrix Metalloproteinase (MMPs) merupakan protease yang banyak berperan dalam persalinan preterm terutama untuk terjadinya pematangan serviks dengan cara mendegradasi kolagen [5]. Kolagen adalah jaringan matriks ekstraseleluler yang fungsinya membuat serviks uteri kuat dan kenyal sehingga bisa mempertahankan hasil konsepsi sampai aterm [14]. Terjadinya persalinan diawali dengan pematangan servik, diikuti oleh kontraksi miometrium dan pecahnya selaput janin [15]. Oleh karena itu, pecahnya selaput ketuban meningkatkan konsentrasi MMPs yang dapat mempercepat pematangan serviks sehingga memicu serangkaian proses sehingga terjadilah persalinan preterm.

Sebaliknya, keberhasilan terapi konservatif pada persalinan preterm disertai ketuban pecah dini perlu ditemukan faktor yang mungkin mendasari keberhasilan terapi tersebut. Setelah dianalisa dari hasil data yang didapat, sampel dengan persalinan preterm disertai ketuban pecah dini yang berhasil diterapi konservatif memiliki rata-rata usia kehamilan paling muda dari kelompok usia pada penelitian ini yaitu antara 24 hingga 28 minggu. Kejadian ini kemungkinan didasari oleh proses penyembuhan spontan selaput ketuban. Secara in vitro, sel satu lapis dari galur sel (FL[ATCC,CCL-62]) yang berasal dari selaput ketuban manusia segar ditemukan mampu memperbaiki defek bedah mikro sentral, dimana $75-80 \%$ defek tersebut diperbaiki dalam waktu 24 jam. Menggunakan galur sel yang sebanding (WISH[ATCC,CCL-25]), ditemukan perbaikan yang dirangsang oleh peningkatan kadar epidermal growth factor dan insulin-like growth factor-1 pada media kultur. Kapasitas perbaikan sel satu lapis tersebut ditemukan sesuai dengan usia kehamilan, yaitu sel yang diperoleh dengan umur kehamilan lebih muda menunjukkan laju proliferasi yang lebih tinggi dan penutupan defek sentral yang lebih cepat [13]. Usia kehamilan berpengaruh pada proses penyembuhan spontan selaput ketuban sehingga kelompok dengan usia kehamilan muda banyak yang berhasil dalam terapi konservatif walaupun persalinan preterm tersebut disertai ketuban pecah dini.

Sampel dengan persalinan preterm tanpa disertai ketuban pecah dini yang diberikan terapi konservatif berjumlah 59 sampel. Dari jumlah tersebut, sampel yang berhasil diterapi konservatif lebih banyak dari pada sampel yang gagal dalam terapi konservatif yaitu 32 dibanding 27. Keberhasilan terapi konservatif pada kelompok ini merupakan kondisi yang sesuai teori bahwa pecahnya selaput ketuban dapat memicu kelahiran yang telah disebutkan di atas sehingga tingkat keberhasilan terapi konservatif persalinan preterm tanpa disertai ketuban pecah dini lebih tinggi. Sebaliknya, kegagalan terapi konservatif yang terjadi pada persalinan preterm tanpa disertai ketuban pecah dini perlu ditemukan faktor apa yang mungkin 
mendasari kegagalan terapi tersebut. Setelah dianalisa dari hasil data yang didapat, sampel dengan persalinan preterm tanpa disertai ketuban pecah dini yang gagal diterapi konservatif memiliki rata-rata usia kehamilan yang paling tua dari kelompok usia pada penelitian ini yaitu antara 32 hingga 33 minggu. Akan tetapi, beberapa penelitian menyebutkan bahwa tidak ada hubungan antara usia kehamilan dengan keberhasilan pemberian tokolitik [16][17][18]. Usia kehamilan tidak bisa dijadikan faktor yang menyebabkan gagalnya terapi konservatif pada persalinan preterm tanpa disertai ketuban pecah dini.

Kegagalan terapi konservatif pada persalinan preterm tanpa disertai ketuban pecah dini kemungkinan dipengaruhi oleh tingkat kontraksi uterus, kondisi selaput ketuban, adanya lendir darah dan dilatasi serviks. Empat faktor klinis tersebut merupakan komponen dari skor tokolitik Baumgarten yang dapat memperkirakan kemungkinan keberhasilan pemberian tokolitik dalam menunda kelahiran. Semakin tinggi poin yang diperoleh dari penjumlahan satiap poin dari faktor klinis tersebut, maka kehamilan semakin beresiko dan keberhasilan penggunaan tokolitik semakin rendah [19]. Gagalnya terapi konservatif pada persalinan preterm tanpa ketuban pecah dini kemungkinan besar karena skor Baumgarten yang tinggi (intensitas kontraksi tinggi dan dilatasi serviks mendekati $3 \mathrm{~cm}$ atau lebih) sehingga kelahiran sudah tidak mampu ditunda lagi dan terapi konservatif gagal walaupun persalinan preterm tersebut tanpa disertai ketuban pecah dini. Kegagalan terapi konservatif pada persalinan preterm tanpa disertai ketuban pecah dini yang melebihi setengah dari jumlah keseluruhan sampel pada kelompok ini dapat dimaklumi karena berdasarkan dari tabel distribusi keberhasilan terapi konservatif, jumlah sampel yang gagal dalam terapi konservatif lebih banyak dari pada sampel yang berhasil yakni sebesar $62,4 \%$ (melebihi setengah dari seluruh sampel penelitian).

Penelitian ini selaras dengan teori yang mendasari hipotesis awal peneliti yaitu teori tentang pecahnya selaput ketuban yang dapat memicu terjadinya persalinan [8][5]. Selain mekanisme tersebut, disebutkan pula bahwa ketuban pecah dini preterm adalah sebuah penyakit dari selaput ketuban, terganggunya faktor-faktor yang saling berinteraksi untuk mempertahankan fungsi integritas dari selaput ketuban memicu terjadinya peningkatan inflamasi steril dan stres oksidatif. kondisi tersebut telah berlangsung sebelum terjadi ketuban pecah dini hingga selaput ketuban akhirnya pecah secara dini. Inflamasi steril berpotensi menambah beban inflamasi yang dapat memicu persalinan [8]. Pecahnya selaput ketuban menyebabkan perlindungan bagi janin kurang adekuat sehingga peran utama selaput ketuban untuk mempertahankan kehamilan kurang maksimal.

Adanya perbedaan signifikan keberhasilan terapi konservatif antara persalinan preterm disertai dan tanpa disertai ketuban pecah dini pada penelitian ini menunjukan bahwa ketuban pecah dini sebagai penyakit penyerta dari persalinan preterm merupakan keadaan yang berisiko karena kemungkinan untuk terjadinya kegagalan pemberian terapi konservatif lebih besar. Pemantauan pada kehamilan baik tunggal, gemelli, atau kehamilan multipel lainnya yang memiliki resiko tinggi untuk mengalami persalinan preterm terutama yang disertai ketuban pecah dini sebaiknya rutin dilakukan. Metode terbaru untuk deteksi dini persalinan preterm adalah dengan Biophysical and Biochemical Screening. Penelitian yang dilakukan selama 15 tahun pada bidang ini menyimpulkan metode-metode terbaik yang bisa digunakan untuk deteksi klinis yakni antara lain menggunakan ultrasonografi transvaginal untuk mengukur panjang leher rahim dan tes fetal fibronektin cervicovaginal. Penelitian ini juga menyarankan penggunaan terapi progesteron, dan cervical cerclage (pengikatan leher rahim) pada ibu hamil beresiko tinggi persalinan preterm. Penelitian selanjutnya ditujukan untuk mengevaluasi lebih lanjut berbagai marker dari persalinan preterm, elektromiografi uterus ibu, dan evaluasi proteomik cairan ibu dan amniotik. Deteksi dini dan pencegahan terjadinya persalinan preterm sangat diperlukan untuk memulai pemberian kortikosteroid lebih awal agar kejadian yang tidak diinginkan karena paruparu yang belum sempurna perkembangannya dapat dikurangi.

Hasil penelitian ini belum bisa digunakan sebagai acuan apalagi untuk diaplikasikan di praktik kedokteran di bidang Obstetri dan Ginekologi, karena jumlah sampel yang diteliti masih terbatas walaupun data rekam medis yang diambil dalam jangka waktu dua tahun. Hal ini dikarenakan kriteria sampel yang dibutuhkan merupakan kelompok dengan jumlah sedikit dalam populasi tersebut, sehingga sampel yang didapat kurang lebih hanya 
seperempat dari jumlah keseluruhaan populasi. Selain itu, karena penelitian ini dilakukan dengan mengambil data sekunder sehingga kelengkapan data tergantung dari penulisan data rekam medis rumah sakit terkait. Terdapat beberapa pasien yang mempunyai rekam medis yang kurang lengkap sehingga menyebabkan sampel yang didapat tidak sepenuhnya mewakili populasi yang diambil dari data rekam medis dalam kurun waktu dua tahun.

\section{Simpulan dan Saran}

Penelitian ini menyimpulkan bahwa terapi konservatif yang diberikan pada persalinan preterm disertai ketuban pecah dini lebih banyak yang gagal daripada yang berhasil, sedangkan terapi konservatif yang diberikan pada persalinan preterm tanpa disertai ketuban pecah dini lebih banyak yang berhasil. Dan terdapat perbedaan yang signifikan dari keberhasilan terapi konservatif antara persalinan preterm disertai dan tanpa disertai ketuban pecah dini di RSD dr. Soebandi Jember.

Beberapa saran yang dapat diberikan antara lain, agar pihak RSD dr. Soebandi melakukan pencatatan status pasien pada rekam medis dengan lebih teratur dan lengkap; selain itu dapat dilakukan penelitian tentang tingkat keberhasilan terapi konservatif pada persalinan preterm usia kehamilan 34 sampai 37 minggu, dikarenakan di Indonesia ibu hamil dengan persalinan preterm usia kehamilan tersebut tetap diberikan terapi konservatif meskipun lebih banyak sumber yang menyebutkan bahwa persalinan preterm dengan usia kehamilan tersebut disarankan untuk dilakukan terapi aktif (delivery advice).

\section{Daftar Pustaka}

[1] World Health Organization. Newborn: Reducing Mortality: WHO; 2016. [cited 09 Juni 2017]. Available from: http://www.who.int/mediacentre/factsheets /fs333/en/.

[2] Sarah AH, Clare M. Management of preterm labour. NHS Foundation Trust, Manchester, UK. Elsevier Inc. 2016.

[3] World Health Organization; 2015. WHO Recommendations On Interventions To Improve Preterm Birth Outcomes. WHO Library Catologuing in Publication Data. ISBN 9789241508988.

[4] World Health Organization. Preterm Birth: WHO; 2016. [cited 09 Juni 2017]. Available

from: http://www.who.int/mediacentre/factsheets /fs363/en/.

[5] Sarwono P. IImu kebidanan. Jakarta: Yayasan Bina Sarwono Prawirohardjo; 2014.

[6] Eliza, Dina DN, dan Rosmiyati. Determinan persalinan prematur di RSUD dr. Abdul Moeloek. Jurnal Kesehatan Politeknik Kesehatan Tanjung Karang. 2017; 8(2): 305-309.

[7] World Health Organization Country Office for Indonesia. Persalinan Preterm. Edukia; 2013. [cited 09 Juni 2017]. Available from: http://www.edukia.org/web/kbibu/6-4-9persalinan-preterm/.

[8] Ramkumar M. Human fetal membranes at term: dead tissues or signalers of parturitions. Elsevier Inc. 2016.

[9] Aviad C, Avital SR, Yoni C, Dror M, Eli R. The influence of prolonged preterm premature rupture of the membranes on neonatal outcome of the presenting and non-presenting twin. European Journal of Obstetrics \& Gynecology and Reproductive Biology. 2014; 181: 28-31.

[10] Priscilla F, Linda D, Anthony A, Krista J. Effects of latency on maternal and neonatal outcomes. J Obstet Gynaecol Can. 2013; 35(8): 710-717.

[11] Elsa L, Pierre YA, Heloise T, Monique K, Bruno L, Damien Subtil, Loic S, Catherine A, Bruno C, Thierry D, Pierre D, Claude $D$, Michel $D$, Cecile $L$, Jaccques EG, Christope V, Norbert W, Laurence FL, Francois G, Gilles K. Impact of latency duration on the prognosis of preterm infants after preterm premature rupture of membranes at 24 to 32 weeks' gestation: a national population-based cohort study. The Journal of Pediatrics. 2017.

[12] Sugiyono. Metode penelitian kuantitatif kualitatif dan R\&D. Edisi 22. Bandung: Alfabeta; 2015.

[13] Jaya K. ketuban pecah dini dan peranan amniopatch dalam penatalaksanaan ketuban pecah dini preterm. Denpasar: SMF Obstetri dan Ginekologi Fakultas Kedokteran Universitas Udayana; 2012.

[14] I Made B, 2013. Peran matriks metalloproteinase (MMPs) pada pematangan serviks dalam kasus persalinan preterm. Denpasar: Program Pasca Sarjana Universitas Udayana; 2013.

[15] Tjokorda GAS. Kerja surfaktan dalam 
pematangan paru bayi preterm. Denpasar: SMF Obstetri dan Ginekologi Fakultas Kedokteran Universitas Udayana; 2013.

[16] Rika E, Joserizal S, Hafni B. Perbedaan rerata kadar IL-6 serum maternal berdasarkan keberhasilan pemberian tokolitik pada partus prematurus imminens. OBGIN EMAS. 2016; 1(2): 16.

[17] Puji I. Perbandingan efektivitas nifedipin dan isoksuprin dalam menghambat proses persalinan preterm. Tesis. Semarang: Program Pendidikan Dokter
Spesialis I Obstetri Ginekologi Universitas Diponegoro; 2013.

[18] Jenny J. Efektivitas dan efek samping ketorolac sebagai tokolitik pada ancaman Persalinan Prematur. Tesis. Semarang: Program Pendidikan Dokter Spesialis I Obstetri Ginekologi Universitas Diponegoro; 2008.

[19] Bensahla TM, Bendaoued D, Bouhassoun $\mathrm{N}$, Boutiba M, Cherif A. La menace d' acchouchement premature. Tlemcen: Universitae Abou Bakr Belkaid; 2013. 